\title{
Evaluation of Hepatitis C Virus Genotype Results in Izmir Atatürk Training and Research Hospital
}

\author{
Izmir Atatürk Eğitim ve Araștırma Hastanesine Bașvuran Hastalarda Hepatitis C Virüs \\ Genotip Sonuçlarının Değerlendirilmesi
}

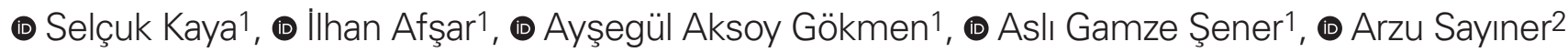 \\ 1 Izmir Katip Çelebi University, Atatürk Training and Research Hospital, Clinic of Microbiology, Izmir, Turkey \\ 2Dokuz Eylül University Faculty of Medicine, Department of Medical Microbiology, Izmir, Turkey
}

\begin{abstract}
Objectives: The aim was to support both the clinical treatment and management and also to contribute to the epidemiological understanding of the hepatitis $\mathrm{C}$ virüs (HCV) genotype in our region. Materials and Methods: HCV genotyping was performed with suspected HCV infection in Izmir Katip Çelebi University, Atatürk Training and Research Hospital, Medical Microbiology Molecular Laboratory. Genotyping of the samples identified as positive for HCV-RNA was performed by Bosphore HCV Genotyping Kit v3.

Results: HCV genotyping results were obtained in 198 (75.8\%) of 261 samples. Genotype 1 was found in 158 (79.8\%) of the 198 samples, genotype 3 was found in $23(11.6 \%)$, genotype 4 in 12 (6\%) and genotype 2 in $3(1.5 \%)$. Genotype 5 was detected in $2(1 \%)$ individuals and one of whom was found to be a foreign national. Four of the 12 individuals identified as genotype 4 were found to be foreign nationals. Of the 158 genotype 1, 131 (82.9\%) were identified as genotype $1 \mathrm{~b}$ and $21(13.3 \%) 1 \mathrm{a}$.

Conclusion: In our hospital, the most prevalent genotype is 1 . This result is compatible with our country.
\end{abstract}

Keywords: Hepatitis C virus, genotype, epidemiology

\section{öz}

Amaç: Bu çalışmada, hepatit $V$ vrüs (HCV)-RNA pozitif hastaların HCV genotip tayinleri retrospektif incelenerek hem klinik tedavi yönetimine destek vermek hem de bölgemizdeki HCV genotip epidemiyolojisine katkı sağlamak amaçlanmıştır.

Gereç ve Yöntemler: Izmir Katip Çelebi Üniversitesi, Atatürk Eğitim ve Araştırma Hastanesi Tıbbi Mikrobiyoloji Moleküler Laboratuvarına HCV genotipleme istenen ve sonuçları çıkanlar çalışmaya alındı. HCVRNA pozitif olarak tespit edilen örneklerin genotipleme çalışması hepatit $C$ virüsü RNA'sının tüm genotiplerini saptayabilen Bosphore HCV Genotyping Kit v3 ile yapıldı.

Bulgular: HCV genotiplendirme çalışılan 261 örneğin 198 (\%75,8) tanesinde sonuç elde edilmiştir. Yüz doksan sekiz örneğin 158'inde $(\% 79,8)$ genotip 1 , 23ünde $(\% 11,6)$ genotip 3,12 sinde $(\% 6)$ genotip 4 ve 3 'ünde $(\% 1,5)$ genotip 2 saptanmıştır. Iki $(\% 1)$ kişide de genotip 5 tespit edilmiş ve bunlardan birinin yabancı uyruklu olduğu görülmüştür. Genotip 4 olarak tespit edilen 12 kişiden 4'ünün yabancı uyruklu olduğu görülmüştür. Genotip 1 olan 158 örneğin 131 'i $(\% 82,9)$ genotip $1 \mathrm{~b} 21^{\prime} \mathrm{i}(\% 13,3)$ 1a olarak tespit edilmiştir. Sonuç: Hastanemizde en sık genotip 1 görülür ve sonuçlar ülkemizle uyumludur.

Anahtar Kelimeler: Hepatit C virüs, genotip, epidemiyoloji

Kaya S, Afşar I, Aksoy Gökmen A, Şener AG, Sayıner A. Evaluation of Hepatitis C Virus Genotype Results in İzmir Atatürk Training and Research Hospital. Viral Hepat J. 2019;25:59-61.

\section{Introduction}

Hepatitis C virus (HCV) is a single-strand positive-directed RNA virus enveloped in the Flaviviridae family. HCV is one of the most important agents of blood-borne diseases such as chronic hepatitis, cirrhosis and hepatocellular carcinoma (1). HCV infects over one hundred million people whole globe including Turkey, where it is a major public health problem that affects large numbers of people $(2,3)$. The rapid replication of the virus and the errors in RNA transcription during this replication play an important role in chronicisation. 
The daily production rate of the HCV is $10^{10}-10^{12}$ virion and the half-life of the virus is two to three hours (3). Genetic diversity is also important for HCV as in other RNA viruses. Genetic diversity is related to the high rate of replication of $\mathrm{HCV}$ and the absence of the function of error repair of RNA dependent RNA polymerase enzyme (4). Molecular epidemiological studies have shown that the distribution and prevalence of subtypes with HCV genotypes are geographically different, and that some genotypes are more dominant in different regions. Some HCV genotypes (genotype 1, 2,3 ) are prevalent whole globe while others (genotypes $4,5,6$ ) are seen in restricted geographical regions (5).

The genotypic variability of the $\mathrm{HCV}$ is a guide in the treatment and follow-up of hepatitis $\mathrm{C}$ patients. From the various studies have been carried out in Turkey it was observed that these were mainly on genotype $1 \mathrm{~b}$. However, there has also been an increase in the number of new HCV genotypes due to the increase in the number of foreign nationals in our country. In this study, HCV genotypes of HCV-RNA positive patients were analyzed retrospectively with the aim of supporting both clinical management and of contributing to the epidemiological understanding of HCV genotype in our region.

\section{Materials and Methods}

The results of HCV genotyping performed on serum samples sent with suspicion of HCV infection at the Izmir Katip Çelebi University, Atatürk Training and Research Hospital Medical Microbiology Molecular Laboratory between January 2013 and December 2017 were included in the study. Demographic data of the patients were obtained from hospital electronic information system and patient files. Ethics committee approval was not required due to the retrospective design of the study. HCV-RNA levels of samples were determined by "real time-polymerase chain reaction (PCR)" method (COBAS AmpliPrep/COBAS Taqman HCV=Roche Diagnostic, Germany). Genotyping of the samples identified as positive for HCV-RNA was performed in the Microbiology Laboratory of Dokuz Eylül University Faculty of Medicine. Genotyping: viral nucleic acid extraction with EZ-1 virus mini kit (Qiagen) was performed. Bosphore HCV Genotyping Kit v3 was used to detect all genotypes of $\operatorname{HCV}$-RNA $(1,1 a, 1 b, 2,3,4,5,6)$ in human serum or plasma samples for HCV genotype determination. The analytical sensitivity of the kit is $100 \mathrm{IU} / \mathrm{mL}$. A portion of the 5 "NS5B region of the HCV genome is amplified and fluorescence detection is performed using FAM, Cy5, and HEX filters. PCR Master Mix 1 in 1, 4, internal control; PCR Master Mix2 1a, 2, internal control;
PCR Master Mix3 3 and internal control; PCR Master Mix4 1 and internal control; 5, 6 in PCR Master Mix5, using different labeled probes for internal control detection. The kit contains an internal control to control nucleic acid isolation and PCR inhibition. During RNA isolation or amplification data of the internal control can be added to the PCR reaction mix were visualized with Cy5 filter.

\section{Statistical Analysis}

SPSS 25.0 (Chicago, IL, USA) software program was used for data analysis. Mann-Whitney $U$ test and Pearson chi-square test were used to evaluate the data; $p<0.05$ was considered statistically significant.

\section{Results}

Between January 2013 and December 2017, the results were obtained in 198 (75.8\%) of 261 samples of HCV genotyping conducted by Izmir Katip Çelebi University, Atatürk Training and Research Hospital Microbiology Laboratory. Genotype 1 was found in $158(79.8 \%)$ of the 198 samples, genotype 3 was found in $23(11.6 \%)$, genotype 4 in $12(6 \%)$ and genotype 2 in $3(1.5 \%)$. Genotype 5 was detected in $2(1 \%)$ individuals and one of them was found to be foreign national. Four of the 12 individuals identified as genotype 4 were found to be foreign nationals. Of the 158 genotype 1, 131 (82.9\%) were identified as genotype $1 \mathrm{~b}$ and 21 (13.3\%) 1a. The age and sex assessment of patients with HCV infection are given in Table 1. There was no statistically significant difference between men and women in terms of gender in patients with $\mathrm{HCV}$ infection ( $p>0.05$ ), but half of them were 55 years of age or older. The mean age of those with genotype $1(58.1+16.7)$ was higher than the mean age $(45.2+14.8)$ in patients infected with other genotypes and this was statistically significant $(p=0.01)$.

\section{Discussion}

The nucleotide sequences of HCV genotypes differ by 31-34\% from each other, the differences of subtypes are $20-23 \%$. Although genotypes have emerged as endemic in geographically distant regions in the long term, most of them are now spread all over the globe. The most prevalent HCV genotype in the globe is 1. Globally, genotype 1 was found in $46 \%$ of all HCV infections. Other genotypes were observed in the following ratios: Genotype 3 (22\%), genotype 2 and 4 (13\% each).Genotype $1 \mathrm{~b}$ is responsible for just $22 \%$ of all infections (6). Genotype $1 \mathrm{~b}$ is the most prevalent and predominant genotype in Turkey and this has been observed again in this study. However, an

\begin{tabular}{|c|c|c|c|c|c|c|c|c|c|c|c|c|c|c|}
\hline \multirow[t]{2}{*}{ Genotype } & \multicolumn{2}{|c|}{$<25$ age } & \multicolumn{2}{|c|}{ 26-35 age } & \multicolumn{2}{|c|}{$36-45$ age } & \multicolumn{2}{|c|}{$46-55$ age } & \multicolumn{2}{|c|}{$56-65$ age } & \multicolumn{2}{|c|}{$>65$ age } & \multicolumn{2}{|l|}{ Total } \\
\hline & $\mathrm{F}$ & $\mathrm{M}$ & $\mathrm{F}$ & $\mathrm{M}$ & $\mathrm{F}$ & $\mathrm{M}$ & $\mathrm{F}$ & $\mathrm{M}$ & $\mathrm{F}$ & $M$ & $\mathrm{~F}$ & $\mathrm{M}$ & $\mathrm{F}$ & $\mathrm{M}$ \\
\hline $1 b$ & 1 & 1 & 3 & 3 & 6 & 11 & 14 & 8 & 16 & 15 & 36 & 17 & 76 & 55 \\
\hline 2 & - & - & - & 1 & 1 & - & - & - & - & 1 & - & - & 1 & 2 \\
\hline 3 & 1 & 4 & 3 & 3 & 2 & 2 & 3 & 2 & 1 & 1 & - & 1 & 10 & 13 \\
\hline 5 & - & - & - & 1 & - & 1 & - & - & - & - & - & - & - & 2 \\
\hline 6 & - & - & - & - & - & - & - & - & - & - & - & - & - & - \\
\hline Total & 4 & 8 & 9 & 11 & 11 & 18 & 20 & 15 & 20 & 18 & 38 & 21 & 102 & 90 \\
\hline
\end{tabular}


increase in the number of the other genotypes in question is also seen. Although it is seen that a section of these are of foreign origin, it is also significant in Turkish citizens. The findings suggest that the distribution of different HCV genotypes in foreign nationals is important. The events that cause social changes such as war and migration and intensive tourist activity affect the epidemiology of infections (7). Izmir is a city where both domestic and foreign tourism is active. It is also a city that attracts refugees and their migration to the city can explain the HCV genotype differences. In the present study genotypes other than genotype 1 were determined as 15\% and genotype 3 was the highest. When we look at the studies published in our country, the highest (40\%) ratio of genotype 3, except for our findings, was determined by Kirişçi et al. (8) in Kahramanmaraş and Sağlık et al.(9) also reported the ratio as $11.1 \%$ in Antalya. However, Kirişçi et al. (8) did not discuss the possible causes of this higher ratio. On the other hand, they reported that they could be associated with tourists coming from abroad, especially from Russia. Buruk et al. (10), in their study carried out in the Eastern Black Sea Region, emphasized that genotype 1 is dominant in similar way to the present study, but that genotypes other than genotype 1 are higher in the cities where people immigrate to and/or where foreign nationals are living than in the country (11-13).

Genotype 4 is the HCV genotype, which is more prevalent in the Middle East countries worldwide (7). Twelve patients had genotype 4, 4 of which were foreign nationals and were from Middle Eastern countries. The highest rate of Genotype 4 in Turkey has been reported in studies to occur in the cities of Kayseri and Afyon $(11,12)$. Because of the long window period of the anti HCV test used in routine diagnosis of HCV, HCV-RNA examination is used by many laboratories $(14,15)$. In the present study, the mean age of those with genotype was found to be higher than other genotypes. This finding is similar to the findings in Antalya (9).

\section{Study Limitations}

We conducted a retrospective study of the records. For this reason, there are some limitations. Some data, including possible transmission routes and risk factors, have not been obtained. Our data supports previous findings showing the dominance of genotype $1 \mathrm{~b}$ infections in the area. However, there is an increase in the rate of infections caused by other genotypes.

\section{Conclusion}

The most prevalant HCV genotype in Turkey is $1 \mathrm{~b}$, however, it can be observed that other genotypes are beginning to be seen in both people of foreign origin and in Turkish citizens. A total prevalence of genotype 1 and 4 with poor prognosis in nine out of every ten people suggests that more attention should be paid to treatment and follow-up.

\section{Ethics}

Ethics Committee Approval: Retrospective study.

Informed Consent: Retrospective study.

Peer-review: External and internal peer-reviewed.

\section{Authorship Contributions}

Concept: S.K., Design: A.A.G., A.G.Ş., I.A., A.S., Data Collection or Processing: S.K., A.S., Analysis or Interpretation: S.K., Literature Search: A.A.G., A.G.S.., I.A., A.S., Writing: S.K.
Conflict of Interest: No conflict of interest was declared by the authors

Financial Disclosure: The authors declared that this study received no financial support

\section{References}

1. Kaya S, Arıdoğan B, Çetin E, Adiloğlu AK, Demirci M. Comparison of polimerase chain reaction and serological methods in the diagnosis of hepatitis $\mathrm{C}$ virus infection. SDU Tıp Fakültesi Dergisi. 2007; 14:10-14.

2. Kaya S, Alanoğlu G, Polat M, Sipahi T. Süleyman Demirel Üniversitesi Tıp Fakültesi Kan Merkezi'nin 2000-2007 yılları tarama test sonuçları. SDU Üniversitesi Tıp Fakültesi Dergisi. 2009;16:13-15.

3. Ural O, Arslan U, Findık D. The distribution of hepatııs $\mathrm{C}$ virus genotype in the Konya Region, Turkey. Turkish Journal of Infection. 2007;21:175-181.

4. Kayman T, Karakükçü C,, Karaman A, Gözütok F. Kayseri bölgesinde Hepatit $C$ virüs enfeksiyonunun genotip dağılımı. Türk Mikrobiyol Cem Derg. 2012;42:21-26.

5. Sağlık I, Mutlu $D$, Öngüt $G$ Inan $D$, Öğünç $D$, Can Sarınoğlu $R$, Özhak Baysan B, Meral Gültekin M, Çolak D. Akdeniz Üniversitesi Hastanesinde kronik hepatit C enfeksiyonu olan hastalarda hepatit $\mathrm{C}$ virus genotipleri. Beş yıllık sonuçların değerlendirilmesi. Mikrobiyol Bul. 2014;48:429-437.

6. Gower E, Estes C, Blach S, Razavi-Shearer K, Razavi H. Global epidemiology and genotype distribution of the hepatitis $\mathrm{C}$ virus infection. J Hepatol. 2014;61:45-57.

7. Magiorkinis G, Magiorkinis E, Paraskevis D, et al. The global spread of hepatitis C virus $1 \mathrm{a}$ and $1 \mathrm{~b}$ : a phylodynamic and phylogeographic analysis. PLoS Med. 2009;6:e1000198.

8. Kirişçi Ö, Çalışkan A, Alkış Koçtürk S, Erdoğmus P, Gül M. The relationship between distribution of HCV-RNA and ALT-AST Levels with genotypes of hepatitis $C$ virus infected patients. Viral Hepatitis Journal 2013;19:67-70.

9. Sağlık I, Mutlu D, Öngut G, Inan D, Öğünç D, Can Sarinoğlu R, Özhak Baysan B, Gültekin M, Çolak D. Distribution of hepatitis C virus genotypes among patients with chronic hepatitis $C$ infection in Akdeniz University Hospital, Antalya, Turkey: A five-year evaluation. Mikrobiyol Bul. 2014;48:429-437.

10. Buruk CK, Bayramoğlu G, Reis A, Kaklıkkaya N, Tosun I, Aydın F. Determination of hepatitis $C$ virus genotypes among hepatitis C patients in Eastern Black Sea region, Turkey. Mikrobiyol Bul. 2013;47:650-657.

11. Çiftci IH, Er H, Aşık G, Aktepe OC, Altındiş M. Hepatit $C$ virusu (HCV) RNA pozitif olgularda genotip dağılımı. Kocatepe Tıp Dergisi. 2009;10:21-24.

12. Gökahmetoğlu S, Atalay MA, Kılınç A. Hepatit C virus genotiplerinin pirosekanslama yöntemi ile belirlenmesi. Erciyes Tıp Dergisi. 2011;33:99-102.

13. Altuğlu I, Sertöz R, Aksoy A, Gürsel D, Tüzüner U, Günşar F. Possible transmission risks and genotype distribution of hepatitis C virus infection in Western Turkey. Turk J Gastroenterol 2013;24:349-355

14. Buket CA, Ayşe A, Selçuk K, Süleyman Ö, Emel SÇ. Comparison of HCV core antigen and anti-HCV with HCV RNA results. Afr Health Sci. 2014;14:816-820.

15. Uzun BK, Er H, Güngör $S$, Şener AG, Kaya $S$. The evaluation of Recombinant Immunoblot assay (RIBA) and HCV-RNA test results in patients with low titer anti-HCV positivity. Journal of Clinical and Experimental Investigations 2014;5: 553-556. 